Federal Reserve Bank of Minneapolis

Research Department

May 1998

\title{
The Suffolk Banking System Reconsidered
}

\author{
Arthur J. Rolnick and Warren E. Weber*
}

Working Paper 587

\begin{abstract}
The best-known example of a privately created and well-functioning interbank payments system is the Suffolk Banking System. Operating in New England between 1825 and 1858, it was the first regionwide net-clearing system for bank notes in the United States. Some historians portray the System as being owned and managed by a coalition of large Boston banks in order to achieve a public purpose. They argue that while the System was not particularly profitable, it maintained par circulation of bank notes throughout the region. We reconsider this history and find the public-purpose view of the Suffolk Banking System to be specious. The System was owned and operated solely by the Suffolk Bank. It was operated not to promote a common currency or any other public purpose, but to serve the private interests of the Suffolk Bank's shareholders, which it did quite successfully.
\end{abstract}

*Rolnick, Federal Reserve Bank of Minneapolis; Weber, Federal Reserve Bank of Minneapolis and University of Minnesota. The authors thank the Baker Library, Harvard Business School, for the materials provided from its Suffolk Bank Collection, and Bruce Smith, Ed Green, Randy Kroszner, Ruilin Zhou, and participants at a seminar at the Federal Reserve Bank of Chicago for their constructive comments. The views expressed herein are those of the authors and not necessarily those of the Federal Reserve Bank of Minneapolis or the Federal Reserve System. 


\section{Introduction}

Before the Civil War, U.S. paper money consisted almost entirely of state bank notes. These notes were liabilities of the bank of issue and were redeemable in specie on demand. Bank notes were issued by virtually every bank in existence, and in the normal course of business, virtually every bank received notes of other banks. Consequently, pre-Civil War banks had a substantial need for some type of note-clearing arrangement.

The best-known example of such an arrangement is the Suffolk Banking System that existed in New England between 1825 and 1858. The System, operated by the Suffolk Bank, was a regionwide clearing system for bank notes. It accepted and net cleared, at par, all the bank notes its members deposited. By the 1830s, most banks in New England had become members of the System, and because of the Suffolk Bank's par-clearing policy, notes of New England banks exchanged at par throughout the region. Par circulation in New England was in notable contrast to other parts of the country, where notes typically exchanged at a discount once they traveled beyond their community.

Historians of the Suffolk Banking System have often portrayed the Suffolk Bank as having a public purpose in running the System. For example, Trivoli $(1979$, pp. 18, 19) reports that in some limited respects, the Suffolk Bank was a private central bank for New England. Calomiris and Kahn (1996) reaffirm this view. They argue that the Suffolk Banking System was a coalition of large Boston banks that was created to serve the public purpose of establishing "a common currency area throughout New England" (p. 774). Calomiris and Kahn (1996) support 
their interpretation of the System by showing that while the System was not particularly profitable, it maintained par circulation of bank notes throughout the region for over 25 years. $^{1}$

In this paper, we reconsider the history of both the Suffolk Bank and the Suffolk Banking System and find the public-purpose view of the Suffolk Banking System to be specious. Our view is that the Suffolk Banking System served not to promote a common currency or any other public purpose, but to serve the private interests of the Suffolk Bank's shareholders. Specifically, we find that the System was owned and operated solely by the Suffolk Bank, not by a coalition of Boston banks. In support of our view, we establish two facts about the Suffolk Bank's profitability. The first is that the Suffolk Bank was extraordinarily profitable relative to other banks in New England at the time. The second is that the Suffolk Bank earned its extraordinary profits from its role as a provider of note-clearing services. Because of the Suffolk Bank's activities as a note clearer, it had a funding source, the specie deposits of member banks, that enabled it to have a higher ratio of assets to capital than other New England banks. This higher asset/capital ratio provided the Suffolk Bank with its higher profits.

\section{The Evolution of the Suffolk Banking System: 1818-1858}

On February 10, 1818, the Suffolk Bank became the seventh bank to be chartered in Boston. Within a year, the Suffolk Bank entered the note-brokering business. While the Suffolk Bank's note-brokering business was never very profitable, it provided the testing ground for the development of a regionwide note-clearing system.

${ }^{1}$ For other studies of the Suffolk Banking System, see Bodenhorn (undated), Whitney (1878), Lake (1947), Redlich (1947), and Mullineaux (1987). 
The Suffolk Bank's brokering business was patterned after the system used by the New England Bank and perhaps other Boston banks at the time. It worked as follows: The Suffolk Bank bought country bank (non-Boston bank) notes from merchants, individuals, and other banks at a discount. It then sent the notes back to the bank of issue for par redemption in specie. However, if the bank of issue kept a non-interest-bearing deposit of at least $\$ 5,000$ at the Suffolk Bank, the bank of issue could repurchase its notes at the same discount paid by the Suffolk Bank. By 1820, the Suffolk Bank found that the cost of returning country bank notes to the bank of issue was not much less than the discount at which the notes were purchased. Competition had made note brokering hardly profitable (Redlich 1947, p. 72).

In April 1824, the Suffolk Bank devised a new strategy for dealing with country bank notes. It formed a coalition with the six other Boston banks to purchase country bank notes and present them for redemption with the goal of eliminating foreign (non-Boston) money from the city of Boston. Each coalition member contributed between $\$ 30,000$ and $\$ 60,000$ to a fund for a total of $\$ 300,000$. This fund was to be used by the Suffolk Bank to purchase country bank notes at "the same or less discount than the New England Bank, or other banks in Boston, received [them], and should send [them] home for redemption" (Whitney 1878, p. 15). Such purchases were to continue indefinitely until country notes ceased to circulate in Boston. The attempt to drive country bank notes out of Boston, however, was unsuccessful.

The failure of this note-purchasing strategy eventually led to the end of the coalition among Boston banks, but not the Suffolk Bank's role in the foreign money business. Indeed, the Suffolk Bank was soon to become the dominant player in this market. In May of 1825, the coalition of city banks, having all but given up on driving country bank notes out of Boston, suggested that the Suffolk Bank allow other banks to deposit all their country bank notes with 
the Suffolk Bank at par and that the Suffolk Bank establish a system to net clear the bank notes it received. No longer would the Suffolk Bank merely buy country bank notes in order to send them back to the issuing bank for redemption; instead, the Suffolk Bank would accept and clear at par all country bank notes deposited by banks that chose to participate in the system. $^{2}$ By 1826 , the city banks had withdrawn from the note-brokering coalition, and most became members of the Suffolk Banking System, the Suffolk Bank's note-clearing business (Suffolk Bank 1826, March 14; Mullineaux 1987, p. 890).

The Suffolk Bank's note-clearing business was similar in many ways to its old notebrokering business. To participate in the System, a country bank had to maintain a permanent, non-interest-bearing deposit with the Suffolk Bank or with another Boston member of the Suffolk Banking System: for each $\$ 100,000$ of capital, the bank had to hold $\$ 2,000$ on deposit. And a country bank had to maintain an additional non-interest-bearing deposit that was, on average, sufficient to redeem its notes received by the Suffolk Banking System. Boston banks had only to hold a permanent, non-interest-bearing deposit. This deposit was initially set at $\$ 30,000$, but was gradually reduced to $\$ 5,000$.

This new arrangement produced two innovations. A major innovation was that bank notes were cleared by netting the accounts of member banks. Before this time, no net-

clearing system for bank notes had been established in the United States. ${ }^{3}$ For example, the (Second) Bank of the United States, which dealt heavily in the notes of state banks, practiced

\footnotetext{
the coalition.

${ }^{2}$ See Redlich (1947, p. 74) on how the idea of a note-clearing system emerged from among members of

${ }^{3}$ Net clearing existed in other countries by this time, however. See, for example, the discussion of note
} 
gross clearing, simply presenting each state bank's notes for redemption in specie. The other innovation was that the Suffolk Bank offered loans - in effect, overdraft privileges- to members of the System. As we will argue, it was these innovations that made participating in the System attractive to most New England banks and ultimately so profitable to the Suffolk Bank.

The netting of bank notes worked as follows: Each day, the notes deposited by member banks with the Suffolk Bank were sorted, and the following day, the net amount was posted to the account of the appropriate bank. The notes of nonmembers banks were sent to the issuing bank for redemption as quickly as possible.

The process of net clearing had value to Suffolk Banking System members because it lowered the cost of redeeming bank notes. Net clearing meant that fewer notes had to travel back to the issuing bank for redemption. Consequently, less specie had to be physically shipped between banks at a time when such shipment was relatively costly.

In its early stages, the Suffolk Banking System was relatively small in its clearing activities, but the business grew rapidly. By the end of 1825, the Suffolk Bank was receiving about $\$ 2$ million a month in country bank notes. This volume of note clearing was dwarfed by the Suffolk Bank's later activities. For instance, the Suffolk Bank cleared \$9 million a month in

1841, $\$ 20$ million a month in 1851 , and close to $\$ 30$ million a month by 1858 (Trivoli 1979 , pp. 15, 21). To put these numbers in perspective, monthly clearing in 1825 amounted to approximately one-half of the stock of notes in circulation in Massachusetts; in 1841 and 1851, clearing in Scotland in Kroszner (1996). 
to the entire stock of notes circulating in Massachusetts; and in 1858, to slightly less than one and a half times the stock of notes circulating in Massachusetts.

We end this brief history of the Suffolk Banking System in 1858 because a new bank, the Bank of Mutual Redemption (BMR), began operating a second note-clearing system at that time. By offering interest on its deposit, the BMR quickly gained a large percentage of the market, and the Suffolk Bank announced that it was exiting the note-clearing business.

\section{The Suffolk Bank's Extraordinary Profits}

That the Suffolk Banking System was a clearinghouse for virtually all New England bank notes is not in dispute. What is in dispute is whether the System acted to serve a public purpose by promoting a common currency or whether it was an enterprise operated solely by the Suffolk Bank to maximize the profits earned by the shareholders of that bank. Our view is that the Suffolk Banking System was operated to serve the interests of the shareholders of the Suffolk Bank. To support our view, we offer evidence that the Suffolk Bank's profits were extraordinarily high relative to other banks in New England at the time and that these extraordinary profits came from the Suffolk Bank's role as a provider of note-clearing services.

One type of evidence that the Suffolk Bank earned higher profits than other Massachusetts banks comes from aggregate data on annual bank dividend rates. Figure 1 plots annual percentage dividend rates for the Suffolk Bank. ${ }^{4}$ For comparison, the figure plots the median dividend rates paid by other large Boston banks and by other Massachusetts banks. ${ }^{5}$

\footnotetext{
${ }^{4}$ The source for all balance sheet data and most dividend data are the Massachusetts bank condition reports listed in the Appendix. Some dividend data also come from Martin (1886).

${ }^{5}$ We do not have direct data on bank profits. However, as argued by Calomiris and Kahn (1996), it appears that during this period, it was standard practice for banks to pay out most or all of their profits as
} 
Figure 2 provides the same information, but

median dividend rates are replaced by average (unweighted) dividend rates of banks in the appropriate categories.

These figures show that there was nothing extraordinary about the Suffolk Bank's profitability from its inception until 1833. During this period, it earned only routine profits, profits very comparable to those of the other Boston and Massachusetts banks. After 1833, the situation changed, however. From 1834 until 1858, the Suffolk Bank consistently paid dividends that were about two percentage points higher than the typical dividends paid either by other large Boston banks or by Massachusetts banks in general. Indeed, in no year after 1833 did the Suffolk Bank pay less than the modal or average dividends. ${ }^{6}$ Thus, the Suffolk Bank was always substantially more profitable than either the typical large Boston bank or the typical Massachusetts bank. This point is important because it indicates that the Suffolk Bank's profit stream was not risky, at least not relative to that of other banks. The Suffolk Bank's high average profits cannot be viewed as providing compensation for some special risks it was taking.

Figures 1 and 2 also indicate that —with the exception of the Suffolk Bank - the other large Boston banks, on average, earned profits very similar to those of their country bank counterparts. This result is consistent with our view that the Suffolk Banking System was not operated on behalf of some larger coalition of Boston banks, as Calomiris and Kahn argue (1996, p. 794). Furthermore, this result explains why Calomiris and Kahn (1996) do not find the

dividends. It is therefore common to use dividends paid as a proxy for profits. Some of the data points in Figures 1 and 2 for 1810-1824 are interpolated because data are not available for every year during that period.

The 12 other Boston banks are City, Commerce, Exchange, Globe, Massachusetts, Merchants', New England, Shoe and Leather Dealers', State, Tremont, Union, and Webster. These are the Boston banks that had capitalizations at least as large as the Suffolk Bank's during the period.

${ }^{6}$ It should be noted that the Suffolk Bank paid a supplemental dividend of 33.3 percent in 1839, which does not appear in our data. 
Suffolk Banking System particularly profitable - they incorrectly assume that the average annual dividend paid by the System was the average paid by the large Boston banks.

Figures 1 and 2 further show that other Massachusetts banks did not share in the increased profits that the Suffolk Bank earned around 1833. Thus, whatever benefits the Suffolk Bank generated for any Suffolk Banking System members other than itself appear largely to have been passed on to bank customers. ${ }^{7}$

Other evidence on the Suffolk Bank's profitability comes from a bank-by-bank comparison. Specifically, for the 28 -year period from 1833 through 1860 , we counted the number of years that any bank had a dividend rate greater than or equal to the Suffolk Bank's. Approximately 100 banks were in existence in Massachusetts throughout this period. The maximum number of years that any bank had a dividend rate at least as great as the Suffolk Bank's was 15, and only one other bank had dividends at least as great as the Suffolk Bank's for at least half the period. In both cases, these banks were small (capital of $\$ 250,000$ or less) country banks. Further, only six banks had dividends at least as great as the Suffolk Bank's for ten or more years, and none of these was located in Boston.

Even more evidence that Suffolk earned higher profits than other Massachusetts banks is provided by Martin (1886), who compiles the high and low stock prices of bank stocks in the Boston stock market. From 1834 to 1858, with the exceptions of only 1839 and 1840, the lowest price for shares of Suffolk Bank stock during the year was higher than the highest price for the stock of any other bank in Boston.

${ }^{7}$ The alternative extreme explanation for the lack of increase in members' profits is that the Suffolk Bank was extracting all the surplus from the Suffolk System. Of course, the truth may lie somewhere between these extremes. 
We now demonstrate that the Suffolk Bank's extraordinary profitability came from its role as a provider of note-clearing services in New England. Our argument is not that the Suffolk Bank was able to earn higher profits than other large Boston banks on any of its individual activities. It seems reasonable to assume that the Suffolk Bank competed with other banks in the markets for loans, note issue, and deposits, so that its returns from these activities were about the same as those of the typical large Boston bank. Instead, our argument is that what accounted for the Suffolk Bank's profitability was that it was the most highly leveraged of all the large Boston banks, and this high degree of leverage came from its note-clearing activities.

The argument that leverage increases bank profit rates goes as follows. Let $\mathrm{A}$ and $\Lambda$ denote the assets and liabilities, respectively, of a bank. Then the profits, $\mathrm{P}$, of the bank are

$$
\mathrm{P}=\mathrm{r}^{\mathrm{a}} \mathrm{A}-\mathrm{r}^{\mathrm{l} \Lambda}
$$

where $\mathrm{r}^{\mathrm{a}}$ and $\mathrm{r}^{1}$ are the rate of interest earned on assets and the rate paid on liabilities, respectively. Substituting the identity that capital, $\mathrm{K}$, is the difference between assets and liabilities, we find that the profit rate, $\pi=\mathrm{P} / \mathrm{K}$, is

$$
\pi=\left(\mathrm{r}^{\mathrm{a}}-\mathrm{r}^{1}\right)(\mathrm{A} / \mathrm{K})+\mathrm{r}^{1}
$$

Thus, when we assume that the rate of return on assets is higher than the rate of interest paid on liabilities, the profit rate (or dividend rate for the banks we are studying here) for a bank increases with its leverage.

In Figure 3, we present the time series for the asset/capital ratios of the Suffolk Bank and the average large Boston bank, and the largest asset/capital ratio for any large Boston bank other than the Suffolk Bank. (Note that this was not the same bank at each time.) Consistent with our argument that its higher leverage is what gave the Suffolk Bank its higher profits, we see that the 
Suffolk Bank always had the highest asset/capital ratio of any large Boston bank. In fact, its asset/capital ratio averaged 3.50. The next largest asset/capital ratio averaged only 2.50 , and the asset/capital ratio for large Boston banks averaged only 1.85 .

To provide some evidence that the asset/capital ratio of a bank is important in explaining its dividend rate, we regressed a bank's dividend rate (expressed in annual terms) on an intercept and its asset/capital ratio in the prior balance sheet nearest the time of the dividend payment. We also included slope and intercept dummies for 1847, when Figures 1 and 2 show a jump in the dividend rates paid by large Boston banks. The sample consisted of all large Boston banks (as given in footnote 5) for the period from 1826 to 1860.

The results are given in Table 1. There we find that a bank's asset/capital ratio is a statistically and economically significant explanatory variable for a bank's dividend ratio. The results show that a bank's dividend rate increases roughly one-for-one with its asset/capital ratio. Since the Suffolk Bank's asset/capital ratio was roughly twice as large as that for the typical large Boston bank, these results show that virtually all of the roughly 2 percentage points that the dividend rate for the Suffolk Bank exceeded that of the other large Boston banks can be attributed to the fact that the Suffolk Bank had a higher asset/capital ratio than the typical large Boston bank. ${ }^{8}$

We now demonstrate that the Suffolk Bank's high degree of leverage came from its provision of note-clearing services. Support for this position comes from contrasting the typical balance sheet of a large Boston bank of the period with a typical balance sheet of the Suffolk

\footnotetext{
${ }^{8} \mathrm{We}$ also ran the regressions allowing separate intercepts and slope coefficients for the Suffolk Bank. The null hypothesis that all these coefficients were simultaneously equal to zero failed to be rejected at any reasonable level of significance for both the case in which an 1847 slope dummy was included and the case in
} 
Bank. A typical balance sheet for a large Boston bank is displayed in Table 2. The entries are averages over the period from 1827 to 1860 and are presented as ratios to capital, because we are interested in comparisons of asset/capital ratios. We note two major points about the balance sheet of the typical large Boston bank. One is that the asset/capital ratio was 1.85 as mentioned above. The other is that deposits of other banks, which were usually called "due to other banks" in the published reports for Massachusetts banks, were only 0.15 times capital.

A typical balance sheet for the Suffolk Bank is presented in Table 3. For several of the items, the balance sheet entries look very similar. In particular, on the asset side, loans were 1.7 times capital for the Suffolk Bank versus 1.5 times capital for the typical large Boston bank, and real estate was 0.1 times capital for the Suffolk Bank versus 0.05 times for the typical large Boston bank. On the liabilities side, deposits were 0.4 times capital for both the Suffolk Bank and the typical large Boston bank, and notes were 0.3 times capital and 0.2 times capital for the two, respectively. For surplus, the numbers were 0.15 versus 0.1 .

However, when the balance sheet items that it could be argued were associated with the Suffolk Bank's activities as a note clearer are compared with the same items for a typical large Boston bank, the similarities end. In particular, what is most important for the sake of our argument is that the Suffolk Bank had "due to other banks" equal to 1.65 times its capital, whereas the typical large Boston bank had only 0.15 times capital. Our interpretation is that these "due to other banks" represented the specie deposits of the banks that were members of the Suffolk Banking System. These deposits, which the Suffolk Bank obtained because of its role as a provider of note-clearing services, provided it with a funding source that was unavailable to

which is was not. 
other banks. Presumably, member banks and other holders of Suffolk Bank liabilities did not view the note-clearing business to be as risky as traditional banking activities. This permitted the Suffolk Bank to maintain a higher asset/capital ratio than other banks in New England and, hence, to earn higher profits.

It should also be noted that on the asset side of its balance sheet, the Suffolk Bank had far larger "due from other banks" than did the typical large Boston bank. This entry included both the Suffolk Bank's deposits at other banks, primarily in New York City, and loans made to other banks. To the extent that this entry includes loans made to other banks, it may also partially account for the Suffolk Bank's higher profitability, since the Suffolk Bank may have had more information about the banks to which it was making loans because of its role as a note clearer. However, this effect is probably small relative to the Suffolk Bank's high leverage ratio, because the market for interbank lending was probably quite competitive.

\section{Summary and Conclusion}

The Suffolk Bank, chartered by the Commonwealth of Massachusetts in 1818, evolved from an ordinary Boston bank into a note-clearing bank for all of New England. Between 1825 and 1858, the Suffolk Bank of Boston operated the Suffolk Banking System, the first regionwide note-clearing system in the United States. We find that, contrary to claims by some historians, the System was not owned by a coalition of Boston banks and was not operated for some public purpose. We find that the Suffolk Bank was the sole owner and operator of the System. And while this note-clearing business led to New England bank notes circulating at par, the Suffolk 
Bank operated the System to earn a profit for its shareholders. Indeed, we found that it earned extraordinary profits for over 25 years.

Future research should focus on whether or not the Suffolk Banking System was truly unique. Some have argued that a Suffolk-type system did not exist in other parts of the country. We think it would be useful to better document the types of note-clearing arrangements that existed elsewhere to determine how they differed from the Suffolk Banking System, and if they were different, what factors would account for the observed features of different payments systems. 


\section{References}

Bodenhorn, Howard. Undated. The end of the Suffolk System: A critical reappraisal. Manuscript. Layfayette College, Easton, $\mathrm{Pa}$.

Calomiris, Charles W., and Kahn, Charles M. 1996. The efficiency of self-regulated payments systems: Learning from the Suffolk System. Journal of Money, Credit, and Banking 28, Part 2 (November): 766-97.

Kroszner, Randall S. 1996. Comment on the efficiency of self-regulated payments systems: Learning from the Suffolk System. Journal of Money, Credit, and Banking 28, Part 2 (November): 798-803.

Lake, Wilfred S. 1947. The end of the Suffolk System. Journal of Economic History 7 (November): 183-207.

Martin, Joseph G. 1886. Martin's Boston stock market: Eighty-eight years. Boston: Joseph G. Martin.

Mullineaux, Donald J. 1987. Competitive monies and the Suffolk Bank System: A contractual perspective. Southern Economic Journal 53 (April): 884-98.

Redlich, Fritz. 1947. The molding of American banking: Men and ideas. New York: Hafner.

Suffolk Bank. 1826. Directors' records, March 14. Available at Baker Library, Harvard Business School.

Trivoli, George. 1979. The Suffolk Bank: A study of a free-enterprise clearing system. London: Adam Smith Institute.

Whitney, D. R. 1878. The Suffolk Bank. Cambridge, Mass.: Riverside Press. 


\section{Appendix}

\section{Sources of Massachusetts Bank Condition Reports}

Secretary of the Commonwealth of Massachusetts. Abstract of Statements of Banks in the Commonwealth, as of these dates:*

$\begin{array}{ll}\text { 1803-January } 1807 & \text { September } 1835 \\ \text { June } 1809 & \text { October } 1836(324) \\ \text { January } 1811 & \text { November } 1837 \\ \text { June } 1811 & \text { October } 1838(348) \\ \text { January } 1812 & \text { November } 1839(367) \\ \text { June } 1813 & \text { October } 1840(385) \\ \text { January } 1814 & \text { September } 1841 \\ \text { June } 1814 & \text { October } 1842 \\ \text { January } 1815 & \text { August } 1843 \\ \text { January } 1819 & \text { July } 1844 \\ \text { January } 1820 & \text { November } 1845(487) \\ \text { June } 1822 & \text { September } 1847(521) \\ \text { January } 1823 & \text { September } 1848 \\ \text { June } 1825 & \text { October } 1849(578) \\ \text { January } 1826 & \text { September } 1850(648) \\ \text { May } 1826 & \text { May } 1851 \\ \text { December } 1826 & \text { September } 1852(684) \\ \text { May } 1827 & \text { October } 1853(725) \\ \text { December } 1827 & \text { August } 1854(788) \\ \text { May } 1828 & \text { August } 1855(858) \\ \text { December } 1828 & \text { October } 1856(909) \\ \text { August } 1829 & \text { October } 1857(958) \\ \text { October } 1831 & \text { October } 1858(1014) \\ \text { August } 1832(234) & \text { October } 1859(1050) \\ \text { October } 1833(259) & \text { October } 1861 \\ \text { May } 1834(287) & \text { July } 1862(1161) \\ \text { October } 1834 & \text { January } 1863(1187) \\ & \end{array}$

*Numbers in parentheses indicate the U.S. Congress serial set volume in which the abstract can be found. 
Federal Reserve Bank of Minneapolis

Research Department

May 1998

\title{
The Suffolk Banking System Reconsidered
}

\author{
Arthur J. Rolnick and Warren E. Weber*
}

Working Paper 587D

\begin{abstract}
The best-known example of a privately created and well-functioning interbank payments system is the Suffolk Banking System. Operating in New England between 1825 and 1858, it was the first regionwide net-clearing system for bank notes in the United States. Some historians portray the System as being owned and managed by a coalition of large Boston banks in order to achieve a public purpose. They argue that while the System was not particularly profitable, it maintained par circulation of bank notes throughout the region. We reconsider this history and find the public-purpose view of the Suffolk Banking System to be specious. The System was owned and operated solely by the Suffolk Bank. It was operated not to promote a common currency or any other public purpose, but to serve the private interests of the Suffolk Bank's shareholders, which it did quite successfully.
\end{abstract}

*Rolnick, Federal Reserve Bank of Minneapolis; Weber, Federal Reserve Bank of Minneapolis and University of Minnesota. The authors thank the Baker Library, Harvard Business School, for the materials provided from its Suffolk Bank Collection, and Bruce Smith, Ed Green, Randy Kroszner, Ruilin Zhou, and participants at a seminar at the Federal Reserve Bank of Chicago for their constructive comments. The views expressed herein are those of the authors and not necessarily those of the Federal Reserve Bank of Minneapolis or the Federal Reserve System. 


\section{Introduction}

Before the Civil War, U.S. paper money consisted almost entirely of state bank notes. These notes were liabilities of the bank of issue and were redeemable in specie on demand. Bank notes were issued by virtually every bank in existence, and in the normal course of business, virtually every bank received notes of other banks. Consequently, pre-Civil War banks had a substantial need for some type of note-clearing arrangement.

The best-known example of such an arrangement is the Suffolk Banking System that existed in New England between 1825 and 1858. The System, operated by the Suffolk Bank, was a regionwide clearing system for bank notes. It accepted and net cleared, at par, all the bank notes its members deposited. By the 1830s, most banks in New England had become members of the System, and because of the Suffolk Bank's par-clearing policy, notes of New England banks exchanged at par throughout the region. Par circulation in New England was in notable contrast to other parts of the country, where notes typically exchanged at a discount once they traveled beyond their community.

Historians of the Suffolk Banking System have often portrayed the Suffolk Bank as having a public purpose in running the System. For example, Trivoli $(1979$, pp. 18, 19) reports that in some limited respects, the Suffolk Bank was a private central bank for New England. Calomiris and Kahn (1996) reaffirm this view. They argue that the Suffolk Banking System was a coalition of large Boston banks that was created to serve the public purpose of establishing "a common currency area throughout New England" (p. 774). Calomiris and Kahn (1996) support 
their interpretation of the System by showing that while the System was not particularly profitable, it maintained par circulation of bank notes throughout the region for over 25 years. ${ }^{1}$

In this paper, we reconsider the history of both the Suffolk Bank and the Suffolk Banking System and find the public-purpose view of the Suffolk Banking System to be specious. Our view is that the Suffolk Banking System served not to promote a common currency or any other public purpose, but to serve the private interests of the Suffolk Bank's shareholders. Specifically, we find that the System was owned and operated solely by the Suffolk Bank, not by a coalition of Boston banks. In support of our view, we establish two facts about the Suffolk Bank's profitability. The first is that the Suffolk Bank was extraordinarily profitable relative to other banks in New England at the time. The second is that the Suffolk Bank earned its extraordinary profits from its role as a provider of note-clearing services. Because of the Suffolk Bank's activities as a note clearer, it had a funding source, the specie deposits of member banks, that enabled it to have a higher ratio of assets to capital than other New England banks. This higher asset/capital ratio provided the Suffolk Bank with its higher profits.

\section{The Evolution of the Suffolk Banking System: 1818-1858}

On February 10, 1818, the Suffolk Bank became the seventh bank to be chartered in Boston. Within a year, the Suffolk Bank entered the note-brokering business. While the Suffolk Bank's note-brokering business was never very profitable, it provided the testing ground for the development of a regionwide note-clearing system.

${ }^{1}$ For other studies of the Suffolk Banking System, see Bodenhorn (undated), Whitney (1878), Lake (1947), Redlich (1947), and Mullineaux (1987). 
The Suffolk Bank's brokering business was patterned after the system used by the New England Bank and perhaps other Boston banks at the time. It worked as follows: The Suffolk Bank bought country bank (non-Boston bank) notes from merchants, individuals, and other banks at a discount. It then sent the notes back to the bank of issue for par redemption in specie. However, if the bank of issue kept a non-interest-bearing deposit of at least $\$ 5,000$ at the Suffolk Bank, the bank of issue could repurchase its notes at the same discount paid by the Suffolk Bank. By 1820, the Suffolk Bank found that the cost of returning country bank notes to the bank of issue was not much less than the discount at which the notes were purchased. Competition had made note brokering hardly profitable (Redlich 1947, p. 72).

In April 1824, the Suffolk Bank devised a new strategy for dealing with country bank notes. It formed a coalition with the six other Boston banks to purchase country bank notes and present them for redemption with the goal of eliminating foreign (non-Boston) money from the city of Boston. Each coalition member contributed between $\$ 30,000$ and $\$ 60,000$ to a fund for a total of $\$ 300,000$. This fund was to be used by the Suffolk Bank to purchase country bank notes at "the same or less discount than the New England Bank, or other banks in Boston, received [them], and should send [them] home for redemption" (Whitney 1878, p. 15). Such purchases were to continue indefinitely until country notes ceased to circulate in Boston. The attempt to drive country bank notes out of Boston, however, was unsuccessful.

The failure of this note-purchasing strategy eventually led to the end of the coalition among Boston banks, but not the Suffolk Bank's role in the foreign money business. Indeed, the Suffolk Bank was soon to become the dominant player in this market. In May of 1825, the coalition of city banks, having all but given up on driving country bank notes out of Boston, suggested that the Suffolk Bank allow other banks to deposit all their country bank notes with 
the Suffolk Bank at par and that the Suffolk Bank establish a system to net clear the bank notes it received. No longer would the Suffolk Bank merely buy country bank notes in order to send them back to the issuing bank for redemption; instead, the Suffolk Bank would accept and clear at par all country bank notes deposited by banks that chose to participate in the system. ${ }^{2}$ By 1826, the city banks had withdrawn from the note-brokering coalition, and most became members of the Suffolk Banking System, the Suffolk Bank's note-clearing business (Suffolk Bank 1826, March 14; Mullineaux 1987, p. 890).

The Suffolk Bank's note-clearing business was similar in many ways to its old notebrokering business. To participate in the System, a country bank had to maintain a permanent, non-interest-bearing deposit with the Suffolk Bank or with another Boston member of the Suffolk Banking System: for each $\$ 100,000$ of capital, the bank had to hold $\$ 2,000$ on deposit. And a country bank had to maintain an additional non-interest-bearing deposit that was, on average, sufficient to redeem its notes received by the Suffolk Banking System. Boston banks had only to hold a permanent, non-interest-bearing deposit. This deposit was initially set at $\$ 30,000$, but was gradually reduced to $\$ 5,000$.

This new arrangement produced two innovations. A major innovation was that bank notes were cleared by netting the accounts of member banks. Before this time, no netclearing system for bank notes had been established in the United States. ${ }^{3}$ For example, the (Second) Bank of the United States, which dealt heavily in the notes of state banks, practiced the coalition.

${ }^{2}$ See Redlich $(1947$, p. 74$)$ on how the idea of a note-clearing system emerged from among members of

${ }^{3}$ Net clearing existed in other countries by this time, however. See, for example, the discussion of note clearing in Scotland in Kroszner (1996). 
gross clearing, simply presenting each state bank's notes for redemption in specie. The other innovation was that the Suffolk Bank offered loans—in effect, overdraft privileges - to members of the System. As we will argue, it was these innovations that made participating in the System attractive to most New England banks and ultimately so profitable to the Suffolk Bank.

The netting of bank notes worked as follows: Each day, the notes deposited by member banks with the Suffolk Bank were sorted, and the following day, the net amount was posted to the account of the appropriate bank. The notes of nonmembers banks were sent to the issuing bank for redemption as quickly as possible.

The process of net clearing had value to Suffolk Banking System members because it lowered the cost of redeeming bank notes. Net clearing meant that fewer notes had to travel back to the issuing bank for redemption. Consequently, less specie had to be physically shipped between banks at a time when such shipment was relatively costly.

In its early stages, the Suffolk Banking System was relatively small in its clearing activities, but the business grew rapidly. By the end of 1825, the Suffolk Bank was receiving about $\$ 2$ million a month in country bank notes. This volume of note clearing was dwarfed by the Suffolk Bank's later activities. For instance, the Suffolk Bank cleared $\$ 9$ million a month in 1841, $\$ 20$ million a month in 1851 , and close to $\$ 30$ million a month by 1858 (Trivoli 1979 , pp. 15, 21). To put these numbers in perspective, monthly clearing in 1825 amounted to approximately one-half of the stock of notes in circulation in Massachusetts; in 1841 and 1851, to the entire stock of notes circulating in Massachusetts; and in 1858, to slightly less than one and a half times the stock of notes circulating in Massachusetts.

We end this brief history of the Suffolk Banking System in 1858 because a new bank, the Bank of Mutual Redemption (BMR), began operating a second note-clearing system at that time. 
By offering interest on its deposit, the BMR quickly gained a large percentage of the market, and the Suffolk Bank announced that it was exiting the note-clearing business.

\section{The Suffolk Bank's Extraordinary Profits}

That the Suffolk Banking System was a clearinghouse for virtually all New England bank notes is not in dispute. What is in dispute is whether the System acted to serve a public purpose by promoting a common currency or whether it was an enterprise operated solely by the Suffolk Bank to maximize the profits earned by the shareholders of that bank. Our view is that the Suffolk Banking System was operated to serve the interests of the shareholders of the Suffolk Bank. To support our view, we offer evidence that the Suffolk Bank's profits were extraordinarily high relative to other banks in New England at the time and that these extraordinary profits came from the Suffolk Bank's role as a provider of note-clearing services.

One type of evidence that the Suffolk Bank earned higher profits than other Massachusetts banks comes from aggregate data on annual bank dividend rates. Figure 1 plots annual percentage dividend rates for the Suffolk Bank. ${ }^{4}$ For comparison, the figure plots the median dividend rates paid by other large Boston banks and by other Massachusetts banks. ${ }^{5}$

\footnotetext{
${ }^{4}$ The source for all balance sheet data and most dividend data are the Massachusetts bank condition reports listed in the Appendix. Some dividend data also come from Martin (1886).

${ }^{5}$ We do not have direct data on bank profits. However, as argued by Calomiris and Kahn (1996), it appears that during this period, it was standard practice for banks to pay out most or all of their profits as dividends. It is therefore common to use dividends paid as a proxy for profits. Some of the data points in Figures 1 and 2 for 1810-1824 are interpolated because data are not available for every year during that period.

The 12 other Boston banks are City, Commerce, Exchange, Globe, Massachusetts, Merchants', New England, Shoe and Leather Dealers', State, Tremont, Union, and Webster. These are the Boston banks that had capitalizations at least as large as the Suffolk Bank's during the period.
} 
Figure 2 provides the same information, but median dividend rates are replaced by average (unweighted) dividend rates of banks in the appropriate categories.

These figures show that there was nothing extraordinary about the Suffolk Bank's profitability from its inception until 1833. During this period, it earned only routine profits, profits very comparable to those of the other Boston and Massachusetts banks. After 1833, the situation changed, however. From 1834 until 1858, the Suffolk Bank consistently paid dividends that were about two percentage points higher than the typical dividends paid either by other large Boston banks or by Massachusetts banks in general. Indeed, in no year after 1833 did the Suffolk Bank pay less than the modal or average dividends. ${ }^{6}$ Thus, the Suffolk Bank was always substantially more profitable than either the typical large Boston bank or the typical Massachusetts bank. This point is important because it indicates that the Suffolk Bank's profit stream was not risky, at least not relative to that of other banks. The Suffolk Bank's high average profits cannot be viewed as providing compensation for some special risks it was taking.

Figures 1 and 2 also indicate that —with the exception of the Suffolk Bank-the other large Boston banks, on average, earned profits very similar to those of their country bank counterparts. This result is consistent with our view that the Suffolk Banking System was not operated on behalf of some larger coalition of Boston banks, as Calomiris and Kahn argue (1996, p. 794). Furthermore, this result explains why Calomiris and Kahn (1996) do not find the Suffolk Banking System particularly profitable - they incorrectly assume that the average annual dividend paid by the System was the average paid by the large Boston banks.

\footnotetext{
${ }^{6}$ It should be noted that the Suffolk Bank paid a supplemental dividend of 33.3 percent in 1839 , which does not appear in our data.
} 
Figure 1 - Median Dividend Rates of Massachusetts Banks, 1807-1861

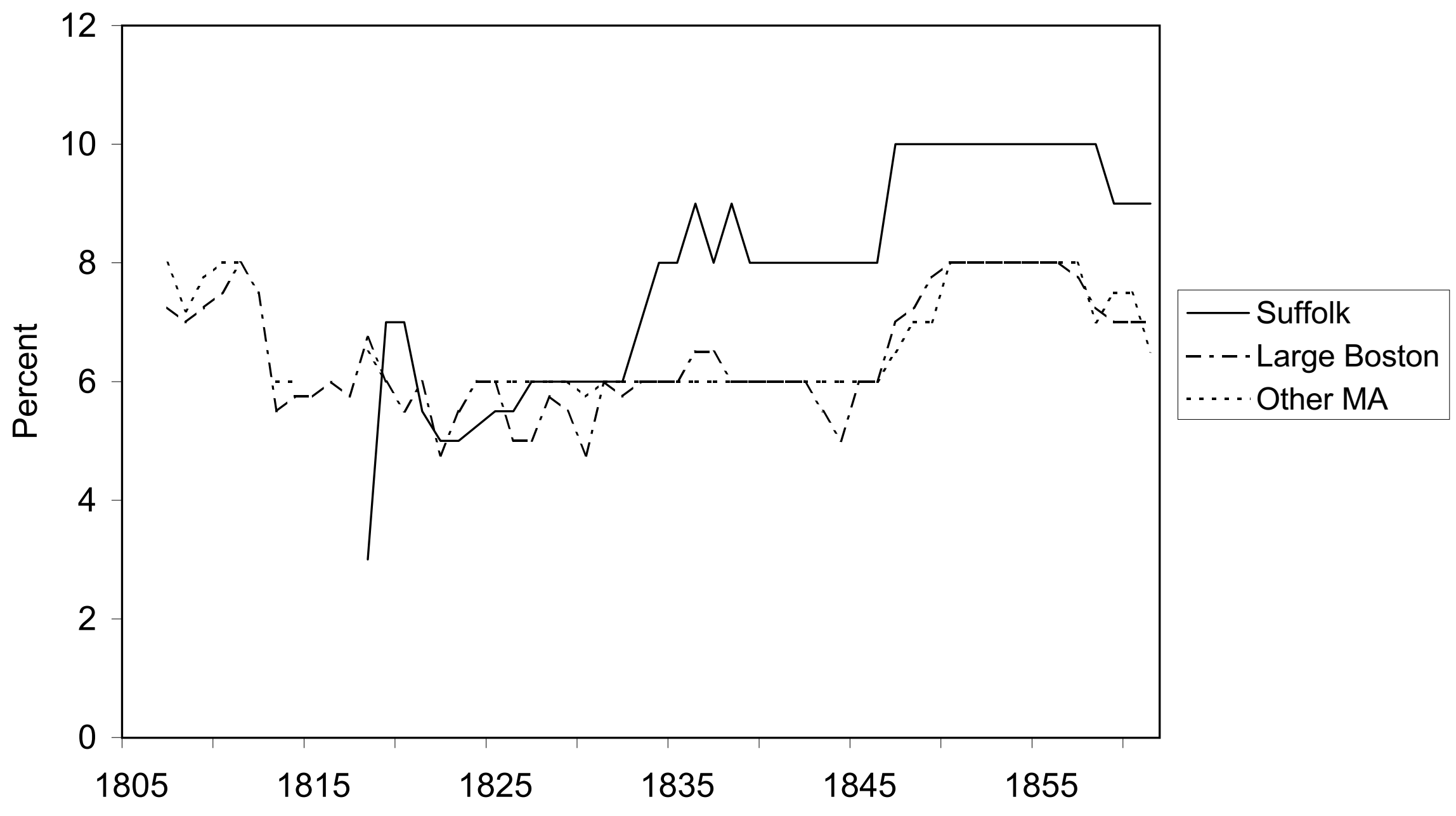


Figure 2 - Average Dividend Rates of Massachusetts Banks, 1807-1861

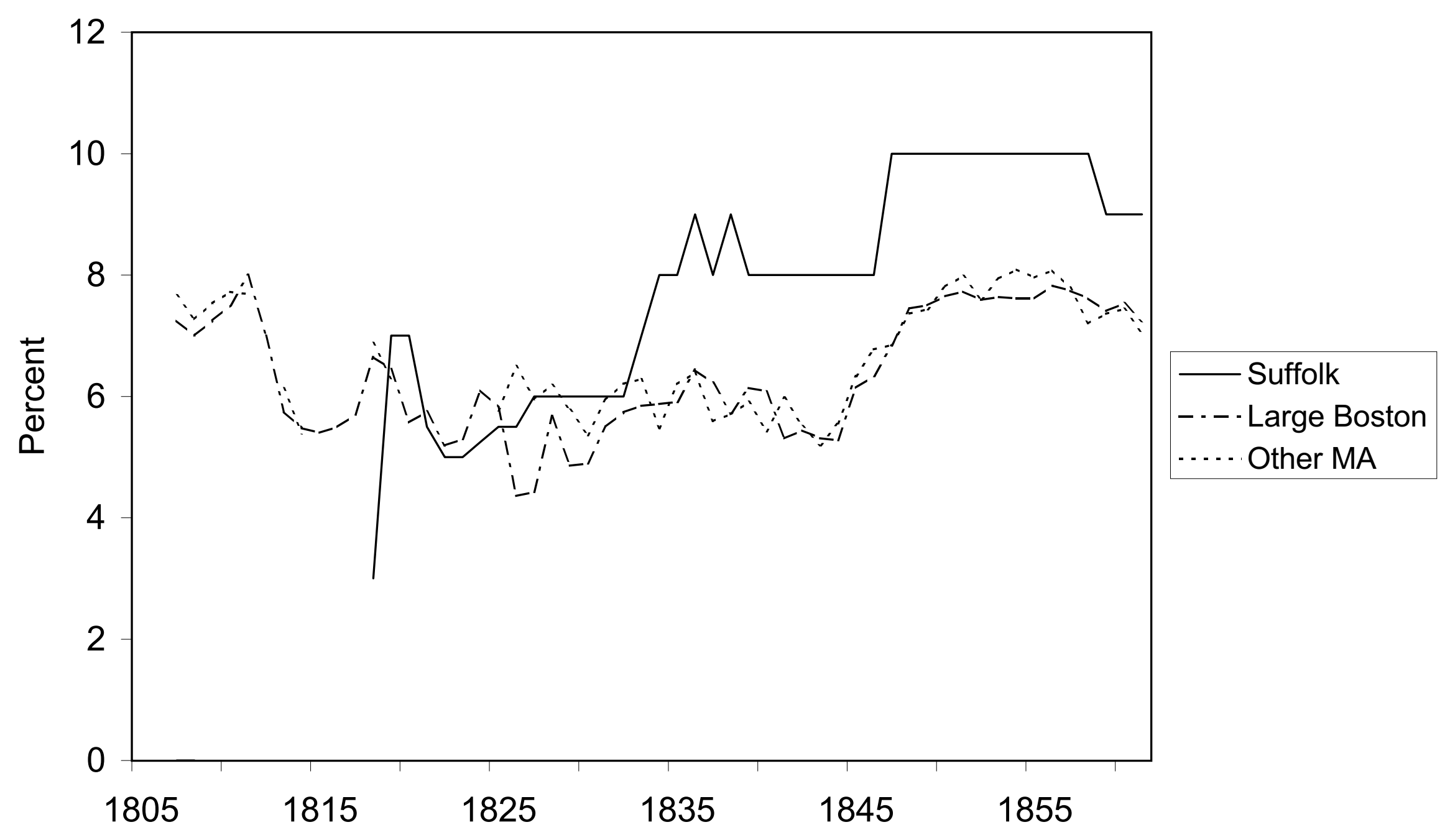


Figures 1 and 2 further show that other Massachusetts banks did not share in the increased profits that the Suffolk Bank earned around 1833. Thus, whatever benefits the Suffolk Bank generated for any Suffolk Banking System members other than itself appear largely to have been passed on to bank customers. ${ }^{7}$

Other evidence on the Suffolk Bank's profitability comes from a bank-by-bank comparison. Specifically, for the 28-year period from 1833 through 1860 , we counted the number of years that any bank had a dividend rate greater than or equal to the Suffolk Bank's. Approximately 100 banks were in existence in Massachusetts throughout this period. The maximum number of years that any bank had a dividend rate at least as great as the Suffolk Bank's was 15, and only one other bank had dividends at least as great as the Suffolk Bank's for at least half the period. In both cases, these banks were small (capital of $\$ 250,000$ or less) country banks. Further, only six banks had dividends at least as great as the Suffolk Bank's for ten or more years, and none of these was located in Boston.

Even more evidence that Suffolk earned higher profits than other Massachusetts banks is provided by Martin (1886), who compiles the high and low stock prices of bank stocks in the Boston stock market. From 1834 to 1858 , with the exceptions of only 1839 and 1840 , the lowest price for shares of Suffolk Bank stock during the year was higher than the highest price for the stock of any other bank in Boston.

We now demonstrate that the Suffolk Bank's extraordinary profitability came from its role as a provider of note-clearing services in New England. Our argument is not that the

${ }^{7}$ The alternative extreme explanation for the lack of increase in members' profits is that the Suffolk Bank was extracting all the surplus from the Suffolk System. Of course, the truth may lie somewhere between these extremes. 
Suffolk Bank was able to earn higher profits than other large Boston banks on any of its individual activities. It seems reasonable to assume that the Suffolk Bank competed with other banks in the markets for loans, note issue, and deposits, so that its returns from these activities were about the same as those of the typical large Boston bank. Instead, our argument is that what accounted for the Suffolk Bank's profitability was that it was the most highly leveraged of all the large Boston banks, and this high degree of leverage came from its note-clearing activities.

The argument that leverage increases bank profit rates goes as follows. Let $\mathrm{A}$ and $\Lambda$ denote the assets and liabilities, respectively, of a bank. Then the profits, $\mathrm{P}$, of the bank are

$$
\mathrm{P}=\mathrm{r}^{\mathrm{a}} \mathrm{A}-\mathrm{r}^{1} \Lambda
$$

where $r^{a}$ and $r^{1}$ are the rate of interest earned on assets and the rate paid on liabilities, respectively. Substituting the identity that capital, K, is the difference between assets and liabilities, we find that the profit rate, $\pi=\mathrm{P} / \mathrm{K}$, is

$$
\pi=\left(\mathrm{r}^{\mathrm{a}}-\mathrm{r}^{1}\right)(\mathrm{A} / \mathrm{K})+\mathrm{r}^{1}
$$

Thus, when we assume that the rate of return on assets is higher than the rate of interest paid on liabilities, the profit rate (or dividend rate for the banks we are studying here) for a bank increases with its leverage.

In Figure 3, we present the time series for the asset/capital ratios of the Suffolk Bank and the average large Boston bank, and the largest asset/capital ratio for any large Boston bank other than the Suffolk Bank. (Note that this was not the same bank at each time.) Consistent with our argument that its higher leverage is what gave the Suffolk Bank its higher profits, we see that the Suffolk Bank always had the highest asset/capital ratio of any large Boston bank. In fact, its 
Figure 3 -- Asset/capital ratios for Massachusetts banks

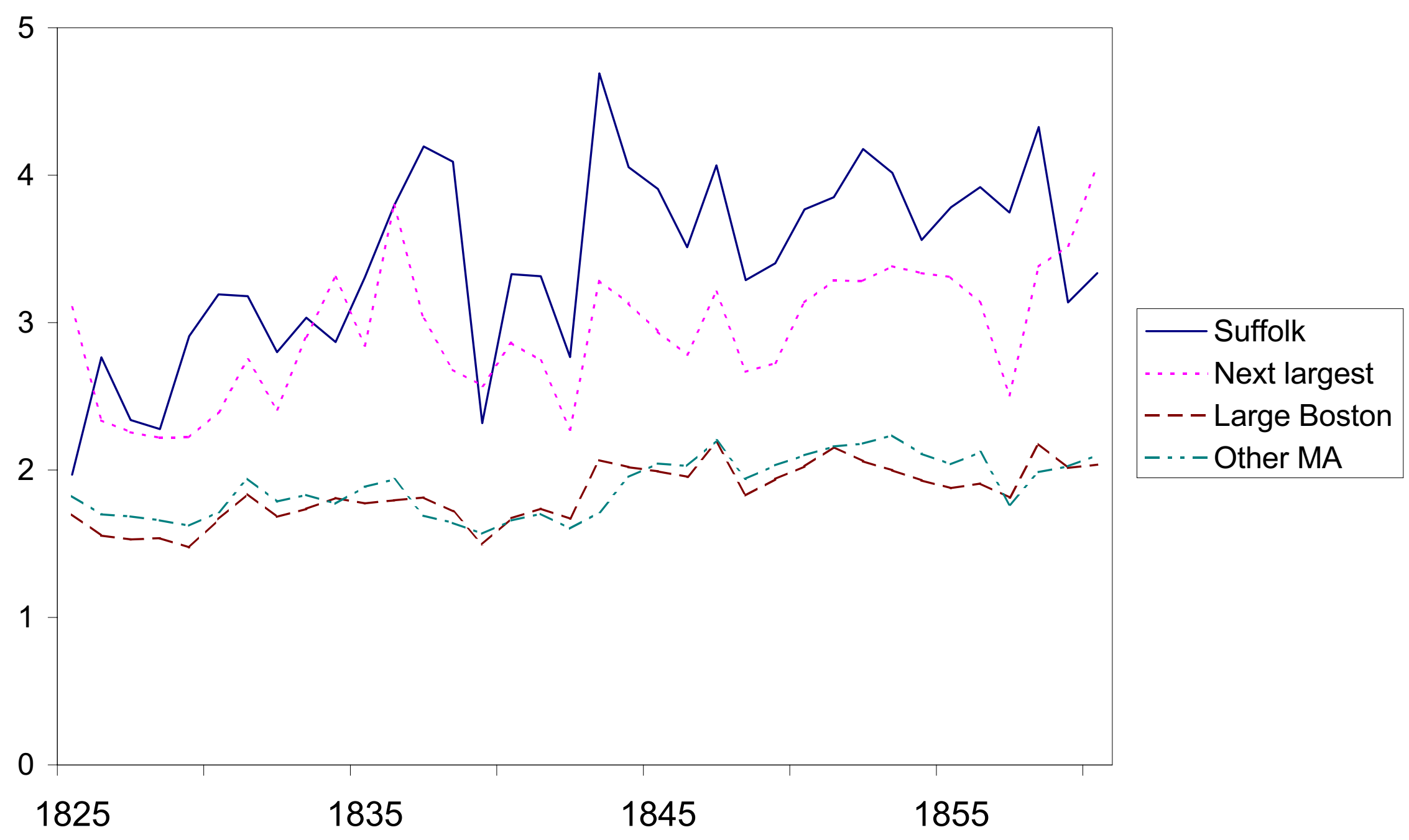


asset/capital ratio averaged 3.50. The next largest asset/capital ratio averaged only 2.50 , and the asset/capital ratio for large Boston banks averaged only 1.85 .

To provide some evidence that the asset/capital ratio of a bank is important in explaining its dividend rate, we regressed a bank's dividend rate (expressed in annual terms) on an intercept and its asset/capital ratio in the prior balance sheet nearest the time of the dividend payment. We also included slope and intercept dummies for 1847, when Figures 1 and 2 show a jump in the dividend rates paid by large Boston banks. The sample consisted of all large Boston banks (as given in footnote 5) for the period from 1826 to 1860.

The results are given in Table 1. There we find that a bank's asset/capital ratio is a statistically and economically significant explanatory variable for a bank's dividend ratio. The results show that a bank's dividend rate increases roughly one-for-one with its asset/capital ratio. Since the Suffolk Bank's asset/capital ratio was roughly twice as large as that for the typical large Boston bank, these results show that virtually all of the roughly 2 percentage points that the dividend rate for the Suffolk Bank exceeded that of the other large Boston banks can be attributed to the fact that the Suffolk Bank had a higher asset/capital ratio than the typical large Boston bank. ${ }^{8}$

We now demonstrate that the Suffolk Bank's high degree of leverage came from its provision of note-clearing services. Support for this position comes from contrasting the typical balance sheet of a large Boston bank of the period with a typical balance sheet of the Suffolk

${ }^{8} \mathrm{We}$ also ran the regressions allowing separate intercepts and slope coefficients for the Suffolk Bank. The null hypothesis that all these coefficients were simultaneously equal to zero failed to be rejected at any reasonable level of significance for both the case in which an 1847 slope dummy was included and the case in which is was not. 
Table 1 - Dividend Regressions for Large Boston Banks

\begin{tabular}{l|ccc|ccc} 
& \multicolumn{3}{c}{ Standard } & \multicolumn{3}{c}{ Standard } \\
Coefficient & Estimate & Error & T-stat & Estimate & Error & T-stat \\
\hline \hline Constant & 3.76 & 0.268 & 14.0 & 3.62 & 0.212 & 17.1 \\
Asset-capital ratio & 1.08 & 0.134 & 8.10 & 1.16 & 0.102 & 13.2 \\
Constant (1847 dummy) & 1.31 & 0.441 & 2.97 & 1.66 & 0.126 & 11.3 \\
Slope (1847 dummy) & 0.171 & 0.207 & 0.826 & & & \\
& & & & & & \\
R2-adj & 0.493 & & & 0.494 & & \\
F-statistic & 123 & $(3,373)$ & & 176 & $(2,373)$ & \\
\hline
\end{tabular}


Bank. A typical balance sheet for a large Boston bank is displayed in Table 2. The entries are averages over the period from 1827 to 1860 and are presented as ratios to capital, because we are interested in comparisons of asset/capital ratios. We note two major points about the balance sheet of the typical large Boston bank. One is that the asset/capital ratio was 1.85 as mentioned above. The other is that deposits of other banks, which were usually called "due to other banks" in the published reports for Massachusetts banks, were only 0.15 times capital.

A typical balance sheet for the Suffolk Bank is presented in Table 3. For several of the items, the balance sheet entries look very similar. In particular, on the asset side, loans were 1.7 times capital for the Suffolk Bank versus 1.5 times capital for the typical large Boston bank, and real estate was 0.1 times capital for the Suffolk Bank versus 0.05 times for the typical large Boston bank. On the liabilities side, deposits were 0.4 times capital for both the Suffolk Bank and the typical large Boston bank, and notes were 0.3 times capital and 0.2 times capital for the two, respectively. For surplus, the numbers were 0.15 versus 0.1 .

However, when the balance sheet items that it could be argued were associated with the Suffolk Bank's activities as a note clearer are compared with the same items for a typical large Boston bank, the similarities end. In particular, what is most important for the sake of our argument is that the Suffolk Bank had "due to other banks" equal to 1.65 times its capital, whereas the typical large Boston bank had only 0.15 times capital. Our interpretation is that these "due to other banks" represented the specie deposits of the banks that were members of the Suffolk Banking System. These deposits, which the Suffolk Bank obtained because of its role as a provider of note-clearing services, provided it with a funding source that was unavailable to other banks. Presumably, member banks and other holders of Suffolk Bank liabilities did not view the note-clearing business to be as risky as traditional banking activities. This permitted 
Table 2 - Balance Sheet of a Typical Large Boston Bank Entries are ratios to capital

\begin{tabular}{ll|ll} 
Assets & \multicolumn{3}{l}{ Liabilities and capital } \\
\hline Loans & 1.50 & Notes & 0.20 \\
Specie & 0.10 & Deposits & 0.40 \\
Bills of other banks & 0.10 & Due to other banks & 0.15 \\
Due from other banks & 0.10 & & \\
Real estate & 0.05 & Capital & 1.00 \\
& & Surplus & 0.10 \\
Total & & & \\
& 1.85 & Total &
\end{tabular}

Table 3 - Balance Sheet of the Suffolk Bank

Entries are ratios to capital

\begin{tabular}{ll|ll} 
Assets & \multicolumn{2}{l}{ Liabilities and capital } \\
\hline Loans & 1.70 & Notes & 0.30 \\
Specie & 0.35 & Deposits & 0.40 \\
Bills of other banks & 0.60 & Due to other banks & 1.65 \\
Due from other banks & 0.75 & & \\
Real estate & 0.10 & Capital & 1.00 \\
& & Surplus & 0.15 \\
& & & \\
Total & 3.50 & Total &
\end{tabular}


the Suffolk Bank to maintain a higher asset/capital ratio than other banks in New England and, hence, to earn higher profits.

It should also be noted that on the asset side of its balance sheet, the Suffolk Bank had far larger "due from other banks" than did the typical large Boston bank. This entry included both the Suffolk Bank's deposits at other banks, primarily in New York City, and loans made to other banks. To the extent that this entry includes loans made to other banks, it may also partially account for the Suffolk Bank's higher profitability, since the Suffolk Bank may have had more information about the banks to which it was making loans because of its role as a note clearer. However, this effect is probably small relative to the Suffolk Bank's high leverage ratio, because the market for interbank lending was probably quite competitive.

\section{Summary and Conclusion}

The Suffolk Bank, chartered by the Commonwealth of Massachusetts in 1818, evolved from an ordinary Boston bank into a note-clearing bank for all of New England. Between 1825 and 1858, the Suffolk Bank of Boston operated the Suffolk Banking System, the first regionwide note-clearing system in the United States. We find that, contrary to claims by some historians, the System was not owned by a coalition of Boston banks and was not operated for some public purpose. We find that the Suffolk Bank was the sole owner and operator of the System. And while this note-clearing business led to New England bank notes circulating at par, the Suffolk Bank operated the System to earn a profit for its shareholders. Indeed, we found that it earned extraordinary profits for over 25 years.

Future research should focus on whether or not the Suffolk Banking System was truly unique. Some have argued that a Suffolk-type system did not exist in other parts of the country. We think it would be useful to better document the types of note-clearing arrangements that 
existed elsewhere to determine how they differed from the Suffolk Banking System, and if they were different, what factors would account for the observed features of different payments systems. 


\section{References}

Bodenhorn, Howard. Undated. The end of the Suffolk System: A critical reappraisal. Manuscript. Layfayette College, Easton, Pa.

Calomiris, Charles W., and Kahn, Charles M. 1996. The efficiency of self-regulated payments systems: Learning from the Suffolk System. Journal of Money, Credit, and Banking 28, Part 2 (November): 766-97.

Kroszner, Randall S. 1996. Comment on the efficiency of self-regulated payments systems: Learning from the Suffolk System. Journal of Money, Credit, and Banking 28, Part 2 (November): 798-803.

Lake, Wilfred S. 1947. The end of the Suffolk System. Journal of Economic History 7 (November): 183-207.

Martin, Joseph G. 1886. Martin's Boston stock market: Eighty-eight years. Boston: Joseph G. Martin.

Mullineaux, Donald J. 1987. Competitive monies and the Suffolk Bank System: A contractual perspective. Southern Economic Journal 53 (April): 884-98.

Redlich, Fritz. 1947. The molding of American banking: Men and ideas. New York: Hafner.

Suffolk Bank. 1826. Directors' records, March 14. Available at Baker Library, Harvard Business School.

Trivoli, George. 1979. The Suffolk Bank: A study of a free-enterprise clearing system. London: Adam Smith Institute.

Whitney, D. R. 1878. The Suffolk Bank. Cambridge, Mass.: Riverside Press. 


\section{Appendix}

\section{Sources of Massachusetts Bank Condition Reports}

Secretary of the Commonwealth of Massachusetts. Abstract of Statements of Banks in the Commonwealth, as of these dates:*

$\begin{array}{ll}\text { 1803-January } 1807 & \text { September } 1835 \\ \text { June } 1809 & \text { October } 1836(324) \\ \text { January } 1811 & \text { November } 1837 \\ \text { June } 1811 & \text { October } 1838(348) \\ \text { January } 1812 & \text { November } 1839(367) \\ \text { June } 1813 & \text { October } 1840(385) \\ \text { January } 1814 & \text { September } 1841 \\ \text { June } 1814 & \text { October } 1842 \\ \text { January } 1815 & \text { August } 1843 \\ \text { January } 1819 & \text { July } 1844 \\ \text { January } 1820 & \text { November } 1845(487) \\ \text { June } 1822 & \text { September } 1847(521) \\ \text { January } 1823 & \text { September } 1848 \\ \text { June } 1825 & \text { October } 1849(578) \\ \text { January } 1826 & \text { September } 1850(648) \\ \text { May } 1826 & \text { May } 1851 \\ \text { December } 1826 & \text { September } 1852(684) \\ \text { May } 1827 & \text { October } 1853(725) \\ \text { December } 1827 & \text { August } 1854(788) \\ \text { May } 1828 & \text { August } 1855(858) \\ \text { December } 1828 & \text { October } 1856(909) \\ \text { August } 1829 & \text { October } 1857(958) \\ \text { October } 1831 & \text { October } 1858(1014) \\ \text { August } 1832(234) & \text { October } 1859(1050) \\ \text { October } 1833(259) & \text { October } 1861 \\ \text { May } 1834(287) & \text { July } 1862(1161) \\ \text { October } 1834 & \text { January } 1863(1187) \\ & \end{array}$

*Numbers in parentheses indicate the U.S. Congress serial set volume in which the abstract can be found. 